\title{
Are all case reports worth publishing?
}

\author{
Tüm olgu sunumları yayımlanmaya değer mi?
}

\author{
O. Şahap Atik, MD. \\ Department of Orthopedics and Traumatology, Medical Faculty of Gazi University, Ankara, Turkey
}

Many original observations, recognition of new diseases, novel diagnostic and therapeutic methods and their complications were first published as case reports..$^{[1]}$ However, some case reports are not worth publishing.

First of all, a case report must be original like any scientific article. ${ }^{[2]}$ It must give a new message. It must be important, too.

Title and abstract should provoke the reader to go on and read the full case report.

Moreover, the case report should include a concise history, physical examination, and laboratory findings, but not unnecessary detail.
How the case report contributes to the medicine must be emphasized.

Also, the patients' informed consent for the publication of the case report must be provided.

Finally, the case report must be written exactly according to the format of the intended journal in terms of shape and content. We believe that wellwritten case reports can play a relevant role in medical education.

\section{REFERENCES}

1. Bagatur AE, Yalçınkaya M. How to write a case report? Or... not write at all? Eklem Hastalık Cerrahisi 2014;25:165-7.

2. Atik OS. How to write a scientific article?. [Article in Turkish] Eklem Hastalik Cerrahisi 2012;23:60. 